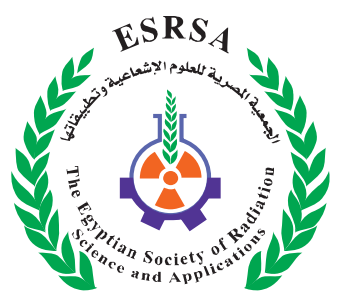

J. Nucl. Tech. Appl. Sci., Vol. 6, No. 1, PP. $13: 29$ (2018)

\title{
Physico-Chemical and Organolyptical Characteristics Of Cake Fortified By Irradiated Broccoli (Brassica Oleracea L.Var Italica) Powder
}

\author{
Khalaf, H.H.A. ${ }^{1}$; El Saadani, R.M.A. ${ }^{1}$; Mervat, M. Anwar ${ }^{2}$ and Hamed Aly ${ }^{2}$
}

Received: 10/01/2018

Accepted: $13 / 02 / 2018$

E.mail:hamedaly86@gmail.com

\section{KEYWORDS}

Broccoli Heads

Powder, Broccoli

Leaves Powder,

Low Caloric Cake,

Replacement, Total

Phenolic Compounds,

Antioxidant, Physical

Properties, Sensory

Properties.

\section{ABSTRACT}

The present study aims to improve the antioxidant and antimicrobial properties of cake and produce low caloric cake through substitution of wheat flour (WF) by irradiated broccoli (Brassica oleracea L.var italica) powder. In this study broccoli heads powder and broccoli leaves powder were gamma irradiated at dose levels of $0,3,5$ and $7 \mathrm{kGy}$. Results showed that ethanolic (70\%) extract of irradiated broccoli heads powder (IBHP) and irradiated broccoli leaves powder (IBLP) at a dose level of 5 $k G y$ had higher total phenolic compounds (TPC) and antioxidant activity (AOA) compared to control and other doses. Thus, IBHP and IBLP at dose level of $5 \mathrm{kGy}$ were selected for fortification of cake. IBHP was used to substitute $(0,1.5,3$, and $4.5 \%)$ of WF in making cake, as well, replacement of WF $(0,1,2$ and $3 \%)$ by IBLP. The results showed that the cake processed from IBHP and IBLP had pronounced improvement (\%) in its chemical composition (protein, lipids, ash and fiber content) while, the energy value and carbohydrate content decreased with increasing the replacement level. Also, the results showed that the TPC content, AOA, volume and specific volume were increased by increasing substitution level of IBHP and IBLP compared to control samples. On the other hand, total intensity, $L^{*}$ and $a^{*}$ values of the crust and crumb were decreased, whereas Chroma and $b^{*}$ values were increased for crumb and decreased for crust for all cake treatments by the addition of IBHP and IBLP compared to control sample. For microbiological properties, the results

\footnotetext{
Food Tech. Dept., Fac. of Agric., Benha Univ., Egypt.

2. Plant Research Department, Nuclear Research Center, Atomic Energy Authority, Inshas, 13759, Egypt.
} 
showed that, increasing of IBHP and IBLP substitution level decreased the microbial count compared to control samples. Finally, the results showed that the sensory characteristics liking results pointed out that a partial replacement of cake flour with less than or equal to (3 and 2\%) IBHP and IBLP, respectively in cake is satisfactory..

\section{INTRODUCTION}

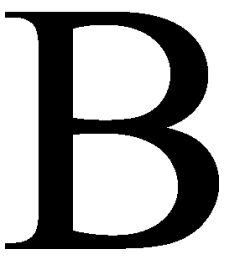

roccoli, (Brassica oleracea L.var. italic), belongs to the family Brassicaceae or Cruciferae (commonly known as the mustard family), genus Brassica and species oleracea (Dixon, 2007; Higdon et al., 2007; Perera et al., 2007; Podsedek, 2007; Jahangir et al., 2009). It is a popular vegetable and healthy horticultural produce with a high nutritional value, due to its significant content of carbohydrates, protein, carotenoids, dietary fiber, niacin and an excellent source of vitamins (C, A and E), folate, antioxidants, anticarcinogenic compounds (such as glucosinolates) and health-promoting phytochemicals (Yuan et al., 2010). It also contains good levels of calcium, iron and potassium (Gourley, 2003; Lister and Bradstock, 2003; Zhang and Hamauzu, 2004).

Moreover broccoli is a rich source of phytochemicals (phenolic Compounds and glucosinolates), Phenolic compounds are known to be the major antioxidants of Brassica crops (Podsedek, 2007). Phenolic compounds have also been reported to act as antimicrobials against pathogenic gram-positive and gram-negative bacteria such as Staphylococcus aureus, Listeria monocytogenes, Escherichia coli, and Salmonella Typhimurium (Caillet et al., 2012), often contamination foods with these bacteria (Giombelli et al., 2015; Maffei et al., 2016).

There are many varieties of green leafy vegetables which are rich in micronutrients, but are usually discarded or not used for human consumption. Broccoli leaves is one of them, which is available at no cost and is rich in all the macronutrient. It is an exceptionally nutritious vegetable with a variety of potential uses. According to FAO, The leaves contribute about $50 \%$ of the total production of broccoli. In the field, up to $70 \%$ of the total weight of the broccoli plant is discarded, generating high quantities of florets, leaves and stalks as crop remains. These materials are often regarded as crop remains and a small percentage is used without treatment in animal feed. Recently, recovery and bioconversion of vegetables residues to high-value compounds has been receiving great attention (Mahro and Timm, 2007). USDA (2011) reported the nutritional value of broccoli leaves as calories $28 \mathrm{kcal}$, protein $3 \mathrm{~g}$, calcium $48 \mathrm{~g}$, iron $0.88 \mathrm{mg}$, vitamin A $16000 \mathrm{IU}$, vitamin C $93.2 \mathrm{mg}$. They also reported that this food is low in saturated fatty acids, and very low in cholesterol. It is also a good source of protein, thiamin, niacin, pantothenic acid, calcium, iron, and selenium and a very good source of vitamin A, Vitamin C, riboflavin, vitamin $\mathrm{B} 6$, folate, magnesium, phosphorus, potassium and magnese.

The use of fruit and vegetable by-products as natural food additives has recently been suggested, due to their high content of polyphenols, carotenoids, dietary fiber, or other bioactive compounds (Blasa et al., 2010; Galanakis et al., 2010; O'Shea et al., 2012; Al-Sayed and Ahmed, 2013).

On the other hand, the content of plant antioxidants and its activity were reported to increase by gamma irradiation (Variyar et al., 1998; Alothman et al., 2009). In this concern, gamma irradiation was applied at various doses to date palm fruit Mazafati, where the amount of total phenolic and antioxidant activity were increased significantly (Ghadi et al., 2015). Also, (Sima et al., 2014) noticed that methanol extract of Curcuma alismatifolia leaves increased total phenolic and antioxidant activity by gamma irradiation.

Bakery products are widely consumed and are becoming a major component of the international 
food market (Kotsianis et al., 2002). Cake is one of the most popular bakery items consumed in the world because of nutritional value, different varieties and affordable price. Lipid oxidation and mold growth are major problems in producing cake, which limits shelf-life of this product. The onset rancidity in bakery products causes a great influence on texture, color and organoleptic parameters, also losses the nutritional value (Sabouri et al., 2012). These problems may be prevented by the use of antioxidants and preservatives (Khaki et al., 2012).

Antioxidants are used as food additives in order to prevent the oxidative deterioration of fats and oils in processed food. There is a great interest nowadays for the use of new natural antioxidants in food, especially in bakery products instead of synthetic antioxidants (Nanditha and Prabhasankar, 2009).

Cake is usually made from soft WF at higher extraction caused deficient in fibers and phytochemicals. On the other hand, the demand for health-oriented products that have high fiber, natural antioxidants, and low calorie contents is increasing because of their beneficial health effects (Rodríguez et al., 2006; Patsioura et al., 2011). Recently, alternative fibers from different sources are available which may provide fibers and phytochemicals as natural components, like fruit, vegetable and their residues (Rodríguez et al., 2006). Broccoli heads and leaves are good sources of natural antioxidants, antimicrobial, phenolic compounds and fibers. Many epidemiological studies assert that fibers consumption helps to reduce obesity, some cancer kinds and cardiovascular diseases. Therefore, the fibers consumption recommended being up to $20-35 \mathrm{~g}$ daily. Newly, some researches were mentioned that food residues could be incorporated into cake making such as carrot leafs (Santos et al., 2014), watermelon rinds and sharlyn melon peels powders (Al-Sayed and Ahmed, 2013), potato peels (Kaack and Pedersen, 2005; Dhingra et al., 2012), flaxseeds (Moraes et al., 2010) and apple pomace (Masoodi et al., 2002;
Sudha et al., 2007). Indeed, incorporating the broccoli head and leaf powders could increase its addedvalue, decrease the cake total manufacturing coast and provide phytochemicals, antioxidants into the human diets.

The aim objective of this study were to determine the effect of the partial replacement of WF by both irradiated dried broccoli heads and leaves powder in cake making to produce low caloric cake, and study the effect of this replacement on chemical composition, antioxidant activity, phenolic compound content, physical, microbiological and organoleptic characteristics of cake during storage at room temperature.

\section{MATERIALS AND METHODS}

\section{Materials:}

\section{Plant samples:}

Fresh whole broccoli (Brassica oleracea L.) was obtained from the farm of agricultural research center on the same day of harvest. Broccoli was separated into two parts: the first part was the heads (flower and portion of stem); the second part was the leaves.

\section{Ingredients of cake:}

Wheat Flour (72\% extraction) was purchased from Algamal flour mills in 6 October city.

Sugar, milk, eggs, fat, baking powder and vanilla were purchased from supermarket, Cairo, Egypt.

\section{Chemicals:}

2,2-Diphenyl-1-picrylhydrazyl (DPPH), gallic acid, Folin- Ciocalteu reagent, were produced by Sigma Chemical Co. (St. Louis, MO, USA). All other used chemicals were analytical grade. All chemicals, reagents and medium (nutrient agar, MacConkey agar, Salmonella Shigella agar and Potato-dextrose agar) of the analytical methods used in present study were purchased from EL.Gamhouria Trading Chemicals and Drugs Co. (Egypt). 


\section{Methods:}

Preparation and irradiation of broccoli heads and leaves samples:

Both of two separated parts (heads and leaves) were rinsed by distilled water, the plant parts were cut into small slices in order to facilitate the drying process, then dried in oven at $45^{\circ} \mathrm{C}$ for $72 \mathrm{~h}$ then ground to a fine powder in a coffec grinder for $2 \mathrm{~min}$, and passed through a 60 mesh sieve to obtain fine homogenous powder. The dried samples were packed in eight packages each containing $200 \mathrm{~g}$ which irradiated to doses of $0,3,5$ and $7 \mathrm{KGy}$, individually, using a ${ }^{60} \mathrm{Co}$ Russian gamma chamber (dose rate $0.98 \mathrm{KGy} / \mathrm{h}$ ) belonging to Cyclotron Project, Nuclear Research Center, Atomic Energy Authority, Cairo, Egypt.

Preparation of broccoli heads and leaves extracts:

Samples of non-irradiated and irradiated dry heads and leaves powder $(10 \mathrm{gm})$ at dose level of 3 , 5 and $7 \mathrm{kGy}$ were soaked individually into $100 \mathrm{ml}$ ethanol $70 \%$. All samples were shaked at room temperature for $7-8 \mathrm{~h}$ at a speed of 1000 vibration/min. Then were filtered through Whatman filter paper No. 1 and the residue was resoaked again in $100 \mathrm{ml}$ of respective solvent to ensure the complete extraction. Filtrate (extract) was subjected to rotary evaporator at $45^{\circ} \mathrm{C}$ under reduced pressure to remove solvent and concentrate to $10 \mathrm{ml}$. The obtained extracts were stored at $-18^{\circ} \mathrm{C}$ in brown bottles to further analyses.

Total Phenolic Compounds and Antioxidant Activity:

\section{Total phenolic compounds:}

Total phenolic compounds content was determined by the Folin-Ciocalteu method according to (Arabshahi-Delouee and Urooj, 2007). A $200 \mu \mathrm{L}$ of cach extract solution was mixed with $1 \mathrm{~mL}$ of FolinCiocalteu's reagent ( $1 \mathrm{ml}$ reagent with $9 \mathrm{ml}$ distilled water) after $5 \mathrm{~min}$ add $1.5 \mathrm{~mL}$ distilled water and $1 \mathrm{~mL}$ of $75 \mathrm{~g} \mathrm{~L}^{-1} \mathrm{Na}_{2} \mathrm{CO}_{3}$ solution. The mixture was incu- bated in a shaking incubator at ambient temperature for $60 \mathrm{~min}$ and its absorbance at $760 \mathrm{~nm}$ was measured. Gallic acid was used as a standard for the calibration curve (correlation coefficient " $\mathrm{R} " \mathrm{2"}=0.9944$ ). Total phenolic content expressed as gallic acid equivalent (GAE) was calculated using the following linear equation based on the calibration curve:

$\mathrm{Y}=0.0045 \mathrm{X}+0.0743$

Where:

Y: is the absorbance.

$\mathrm{X}$ : is the concentration ( $\mathrm{mg} \mathrm{GAE} \mathrm{g}^{-1}$ extract).

Determination of antioxidant activity:

The antioxidant activity (AOA) was determined using DPPH assay according to (Hanato et al., 1988) with minor modification. A $0.1 \mathrm{ml}$ of each extract was vortexed for $30 \mathrm{~s}$ with $3.9 \mathrm{ml}$ of $0.1 \mathrm{mM} \mathrm{DPPH}^{\bullet}$ solution and left to react for $30 \mathrm{~min}$ at room temperature, afterword the absorbance was determined against a control at $517 \mathrm{~nm}$ (Gulcin et al., 2004). Percentage of antioxidant activity of free radical DPPH was calculated as follows:

Antioxidant activity (Inhibition) $\%=$

$\left[\left(\mathrm{A}_{\text {control }}-\mathrm{A}_{\text {sample }}\right) / \mathrm{A}_{\text {control }}\right] \times 100$

Where: $A_{\text {control }}$ is the absorbance of the control reaction and $\mathrm{A}_{\text {sample }}$ is the absorbance in the presence of sample extract.

\section{Preparation of cake samples:}

Cakes were prepared according to the method described by (Lu et al., 2010) using the following formula: $1000 \mathrm{~g} \mathrm{WF}$ (72\% extraction) without antioxidants, $850 \mathrm{~g}$ sugar, $50 \mathrm{~g}$ shortening, $40 \mathrm{~g}$ baking powder, $250 \mathrm{~g}$ eggs, $200 \mathrm{ml}$ milk and $17 \mathrm{~g}$ vanilla. The ingredients were mixed for 3-4 minutes and placed on aluminum cups then backed in an oven at $180^{\circ} \mathrm{C}$ $\pm 5^{\circ} \mathrm{C}$ for $30-35 \mathrm{~min}$, after achieving the following treatments. Cakes were prepared to provide seven samples: The first sample without treatment (con- 
trol). The second sample was prepared by replacing WF by $1.5 \%$ irradiated broccoli heads powder (IBHP) While, the other samples were prepared by replacing WF by $3 \%$ and $4.5 \%$ IBHP, $1 \%, 2 \%$ and $3 \%$ irradiated broccoli leaves powder (IBLP). Cake samples were stored at room temperature $\left(25^{\circ} \mathrm{C} \pm 2\right)$ for 18 days.

\section{Approximate Chemical Composition:}

Moisture, ash, protein, fat and crude fiber of all cake samples, IBHP and IBLP samples were determined according to the methods described in (A.O.A.C., 2012). The carbohydrate was calculated by difference as follows:

Total carbohydrate $=100-(\%$ moisture $+\%$ protein $+\%$ fat $+\%$ ash $+\%$ fiber $)$. To calculate the food energy value, the main components were converted using conversion factors as $(4.0 \mathrm{kcal} / \mathrm{g})$ for proteins and available carbohydrates, $(9.0 \mathrm{kcal} / \mathrm{g})$ for fats, according to (FAO, 2003).

\section{Physical analyses of cake:}

Determination of weight, volume and specific volume for cake samples:

Cake mass was weighted after 3 hours at room temperature. The volume $\left(\mathrm{cm}^{3}\right)$ was measured by replacement method described in the (A.A.C.C., 1983). The specific volume was obtained by dividing the volume of cakes by their weights.

\section{Determination of cake color samples:}

Crumb and crust color of fresh cake was measured with a Hunter lab DP 9000 D 52L optical sensor using $L^{*}, a^{*}$ and $b^{*}$ color scale. The instrument was standardized each time with a white and black ceramic plate. The samples were scanned at five different locations and the mean values of $L, a, b$ were recorded. The total color change $(\Delta \mathrm{E})$ of each cake was calculated as described by (Mai et al., 2007) as follows $\Delta E=\left[\left(L^{*}-L\right)^{2}+\left(a^{*}-a\right)^{2}+\left(b^{*}-b\right)^{2}\right]^{1 / 2}$. Where $L^{*}, a^{*}$ and $b^{*}$ are the lightness, redness and yellow- ness color score respectively at time zero. The L, a, and $\mathrm{b}$ represented the instantaneous individual reading. The Chroma (C) represents color saturation or purity was calculated from $\mathrm{C}=\left(\mathrm{a}^{2}+\mathrm{b}^{2}\right)$ and total color intensity $=\left(a^{2}+b^{2}+L^{2}\right)^{1 / 2}$.

\section{Microbiological analyses of cake:}

\section{Bacteriological Methods:}

\section{Total plate bacterial count:}

The total plate bacterial counts were determined using the plate counts technique on a nutrient agar medium according to the procedures described in (APHA, 1992). The plates were incubated at $37^{\circ} \mathrm{C}$ for $48 \mathrm{hrs}$.

\section{Coliform bacterial count:}

The coliform bacteria were determined using MacConkey agar medium according to the procedures described in (APHA, 1992). The plates were incubated at $37^{\circ} \mathrm{C}$ for $24 \mathrm{hrs}$.

\section{Detection of salmonella:}

The presence or absence of Salmonella was determined according to the method described by (FAO, 1979). Salmonella Shigella agar plates were incubated at $35^{\circ} \mathrm{C}$ for $24 \mathrm{~h}$. Salmonella appeared as black colonies, some of them with metallic sheet.

\section{Molds and Yeasts methods:}

The procedures of (APHA, 1992) were followed for the determination of mold and yeast counts using potato-dextrose agar medium. The plates were incubated at $20-25^{\circ} \mathrm{C}$ for 5 days.

\section{Sensory properties of cake samples:}

All cake samples were periodically examined (every 6 days) by ten panelists from the staff members of Food irradiation unit, Plant Research Department, Nuclear Research Center. Panelists were asked to score the quality attributes of each cake sample. Appearance, crust color, crumb color, taste, odor and 
overall acceptability were judged on a scale of 10 according to (A.A.C.C., 1996).

\section{Statistical Analysis:}

The data obtained from three replicates were analyzed by (ANOVA) using the SPSS statistical package program, and differences among the means were compared using the

Duncan's Multiple Range test SPSS (1998). A significant level of 0.05 was chosen.

\section{RESULTS AND DISCUSSION}

Effect of gamma irradiation on total phenolic content (TPC) and antioxidant activity (AOA) of broccoli heads and leaves extracts:

Data in Table (1) shows that different dose levels $(3,5$ and $7 \mathrm{kGy})$ increased the TPC content and the DPPH radical scavenging activities in both heads and leaves powders compared to non-irradiated sample.

Table (1) : Total phenolic and DPPH radical scavenging activity of the non-irradiated and irradiated broc coli heads and leaves powder extracts.

\begin{tabular}{|c|c|c|c|c|}
\hline \multirow{3}{*}{ Doses } & \multicolumn{4}{|c|}{ Samples } \\
\hline & \multicolumn{2}{|c|}{ Broccoli heads powder } & \multicolumn{2}{|c|}{ Broccoli leaves powder } \\
\hline & $\begin{array}{c}\text { TPC } \\
(\mathrm{mg} \mathrm{GAE} / 100 \mathrm{~g})\end{array}$ & DPРH\% & $\begin{array}{c}\text { TPC } \\
(\mathrm{mg} \mathrm{GAE} / 100 \mathrm{~g})\end{array}$ & DPPH\% \\
\hline 0 kGY & $916.55^{\mathrm{C}} \pm 2.13$ & $78.84^{\mathrm{R}} \pm 0.47$ & $1187.68^{\mathrm{B}} \pm 2.10$ & $88.23^{\mathrm{B}} \pm 0.12$ \\
\hline $3 \mathrm{kGY}$ & $921.64^{\mathrm{C}} \pm 2.90$ & $81.33^{\mathrm{A}} \pm 0.30$ & $1205.04^{\mathrm{B}} \pm 1.86$ & $88.59^{\mathrm{B}} \pm 0.15$ \\
\hline $5 \mathrm{kGY}$ & $1132.75^{\mathrm{A}} \pm 2.68$ & $82.33^{\mathrm{A}} \pm 0.32$ & $1299.26^{\mathrm{A}} \pm 2.47$ & $89.87^{\mathrm{A}} \pm 0.29$ \\
\hline $7 \mathrm{kGY}$ & $980.97^{\mathrm{B}} \pm 2.12$ & $81.42^{\mathrm{A}} \pm 0.24$ & $1286.01^{\mathrm{A}} \pm 1.92$ & $88.75^{\mathrm{B}} \pm 0.24$ \\
\hline
\end{tabular}

(Means $\pm S E$ ).

A.B.C: Means with the same letter in the same column are not significantly different $(p>0.05)$

The ethanolic $70 \%$ extract of irradiated heads at dose level of $5 \mathrm{kGy}$ has a clear significant $(p<0.05)$ increase in TPC contents and the DPPH radical scavenging activities as compared to that of the control sample and other doses, which it were $916.55 \mathrm{mg}$ GAE $/ 100 \mathrm{~g}$ DW and $78.84 \%$, respectively in control and increased to $1132.75 \mathrm{mg} \mathrm{GAE} / 100 \mathrm{~g}$ DW and $82.33 \%$, respectively after irradiation treatment.

In the case of leaves, as also shown in Table (1) the irradiation treatment had the same manner of acting for TPC contents and DPPH radical scavenging activities of IBHP.

Generally the different dose levels increased the content of TPC and enhanced the DPPH scavenging activity of the ethanol $70 \%$ extracts of the samples compared to non-irradiated sample. The ethanolic $70 \%$ extract of irradiated leaves at dose level of
$5 \mathrm{kGy}$ recorded the highest values of TPC content and DPPH radical scavenging activities being $1299.26 \mathrm{mg}$ GAE $/ 100 \mathrm{~g}$ DW and $89.87 \%$, respectively. While the non-irradiated sample recorded the lowest values of TPC content and DPPH radical scavenging activities.

The results showed that ethanolic 70\% extract of irradiated broccoli heads powder (IBHP) and irradiated broccoli leaves powder (IBLP) at a dose level of $5 \mathrm{kGy}$ extract had higher total phenolic compounds (TPC) and antioxidant activity (AOA) compared to other doses. Thus, IBHP and IBLP at dose level of 5 $\mathrm{kG}$ y were selected to add in cake making.

Chemical composition of wheat flour (WF), irradiated broccoli heads (IBHP) and irradiated broccoli leaves (IBLP) powder at dose level of $5 \mathrm{kGy}$ :

The proximate chemical composition of WF, IBHP and IBLP are present in Table (2). 
Table (2) : Chemical composition of WF, IBHP and IBLP at dose level of $5 k G y$.

\begin{tabular}{|c|c|c|c|}
\hline Components & WF 72\% & IBHP & IBLP \\
\hline Moisture (\%) & $13.22^{\mathrm{A}} \pm 0.13$ & $10.59^{\mathrm{B}} \pm 0.14$ & $9.33^{\mathrm{C}} \pm 0.17$ \\
\hline Crude protein (\%) & $15.19^{\mathrm{B}} \pm 0.16$ & $19.84^{\mathrm{A}} \pm 0.09$ & $15.84^{\mathrm{C}} \pm 0.12$ \\
\hline Ether extract (\%) & $1.74^{\mathrm{B}} \pm 0.034$ & $3.71^{\mathrm{B}} \pm 0.04$ & $4.04^{\mathrm{A}} \pm 0.05$ \\
\hline Ash (\%) & $0.88^{\mathrm{C}} \pm 0.04$ & $7.32^{\mathrm{B}} \pm 0.07$ & $13.96^{\mathrm{A}} \pm 0.08$ \\
\hline Crude fiber (\%) $^{\mathrm{C}} \mathbf{\%}$ & $0.58^{\mathrm{C}} \pm 0.025$ & $10.38^{\mathrm{A}} \pm 0.09$ & $9.76^{\mathrm{B}} \pm 0.09$ \\
\hline Carbohydrates (\%) $^{\text {(\%) }}$ & $68.39^{\mathrm{A}} \pm 0.21$ & $48.16^{\mathrm{B}} \pm 0.13$ & $47.07^{\mathrm{C}} \pm 0.05$ \\
\hline $\begin{array}{c}\text { Energy value } \\
\text { (kcal 100 g }\end{array}$ & $349.98^{\mathrm{A}} \pm 0.45$ & $305.39^{\mathrm{B}} \pm 1.2$ & $288^{\mathrm{C}} \pm 0.78$ \\
\hline
\end{tabular}

(Means $\pm S E)$.

A.B.C. Means with the same letter in the same raw are not significantly different $(p>0.05)$.

*Total carbohydrate was calculated by difference.

From statistical analysis of these data it could be noticed that a significant differences $(p<0.05)$ were recorded in the gross chemical composition between all the tested raw materials. The obtained results revealed that WF recorded the highest moisture content being $13.22 \%$, while IBHP and IBLP had lower moisture content being 10.59 and $9.33 \%$, respectively.

On the other hand, IBHP had the highest crude protein and crude fiber content being 19.84 and $10.38 \%$, respectively, followed by IBLP where they were 15.84 and $9.76 \%$, respectively. IBLP had the highest ether extract and ash content being 4.04 and $13.96 \%$ respectively, followed by IBHP 3.71 and $7.32 \%$, respectively. While WF had the lowest value of crude protein, ether extract, ash and crude fiber content being $15.19,1.74,0.88$ and $0.58 \%$, respectively. WF recorded the highest values of carbohydrate being $68.39 \%$, followed by IBHP being $48.16 \%$. Meanwhile, IBLP had the lowest carbohydrate $47.07 \%$. Also, WF recorded the highest en-

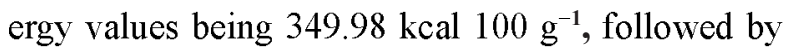

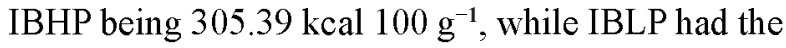

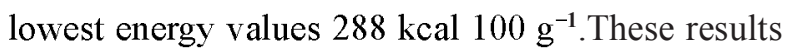
are nearly close to the results obtained by (Ali and Halim, 2013; Sankhon et al., 2013; Madhu and Kochhar, 2014). The difference in chemical composition is due to the variation in the environmental con- ditions, mainly temperature, soil fertility, agronomic practices such as irrigation, fertilization, harvest and the maturity stage of broccoli and wheat plants.

Chemical composition of cake fortified by IBHP and IBLP at dose level of $5 \mathrm{kGy}$ :

Proximate chemical analysis of WF cake, cake fortified by with $1.5,3$ and $4.5 \%$ of IBHP; 1,2 and $3 \%$ for IBLP are tabulated in Table (3). From these results it could be observed that, there were significant differences $(p<0.05)$ in ash and crud fiber contents between all fortified cake treatments and control cake sample. On the other hand, there were no significant differences ( $p>0.05)$ in moisture, protein, ether extract, carbohydrate and energy values for fortified cake samples compared with control.

Data in Table (3) showed that, protein and ether extract contents from different fortified cake samples were increased as the percentage of IBHP and IBLP increase, but no significant different between all samples treatment and control sample, Also ash and fiber contents of cake samples were increased as increasing the replacement level of WF by IBHP and IBLP with Significant deferent between control and some sample treatment. In the same time, carbohydrate and energy value were decreased as the level of replacement increased, but no significant different between all samples treatment and control sample 
except for IBHP and IBLP powder at 4.5 and 3 concentrate respectively. These results are in agreement with (Menon et al., 2014;Prokopov et al., 2015).

Generally, it could be seen that cake processed from the investigated IBHP and IBLP had pro- nounced improvement $\%$ in its chemical composition (protein, lipids, ash and fiber content) excepted the energy value and carbohydrate content decreased with increasing the replacement level, which means the possibility of producing a cake with high nutritional value and low caloric.

Table (3) : Chemical composition of different cake treatment as affected by IBHP and IBLP at dose level of $5 k G y$.

\begin{tabular}{|c|c|c|c|c|c|c|c|}
\hline \multirow{3}{*}{ Characteristics } & \multirow{3}{*}{ Control } & \multicolumn{6}{|c|}{ Treatments } \\
\hline & & \multicolumn{3}{|c|}{ IBHP } & \multicolumn{3}{|c|}{ IBLP } \\
\hline & & $1.5 \%$ & $3 \%$ & $4.5 \%$ & $1 \%$ & $2 \%$ & $3 \%$ \\
\hline Moisture (\%) & $26.7^{\mathrm{A}} \pm 0.38$ & $26.69^{A} \pm 0.35$ & $26.82^{\mathrm{A}} \pm 0.36$ & $26.39^{A} \pm 0.53$ & $26.71^{\mathrm{A}} \pm 0.74$ & $26.68^{\mathrm{A}} \pm 0.70$ & $26.59^{\mathrm{A}} \pm 1.01$ \\
\hline Protein $(\%)$ & $\begin{array}{c}12.73^{\mathrm{A}} \\
\pm 0.13 \\
\end{array}$ & $12.77^{\mathrm{A}} \pm 0.20$ & $12.82^{\mathrm{A}} \pm 0.20$ & $12.85^{\mathrm{A}} \pm 0.45$ & $12.72^{\mathrm{A}} \pm 0.19$ & $12.76^{\mathrm{A}} \pm 0.13$ & $12.79^{A} \pm 0.15$ \\
\hline $\begin{array}{c}\text { Ether extract } \\
(\%)\end{array}$ & $9.69^{A} \pm 0.10$ & $9.71^{\mathrm{A}} \pm 0.14$ & $9.76^{\mathrm{A}} \pm 0.11$ & $9.79^{A} \pm 0.19$ & $9.72^{A} \pm 0.18$ & $9.75^{\mathrm{A}} \pm 0.15$ & $9.78^{A} \pm 0.17$ \\
\hline Ash (\%) & $1.53^{\mathrm{D}} \pm 0.08$ & $1.75^{\mathrm{CD}} \pm 0.05$ & $1.95^{\mathrm{ABCD}} \pm 0.12$ & $2.29+\mathrm{A} \pm 0.17$ & $1.89^{\mathrm{BCD}} \pm 0.12$ & $2.12^{A B C} \pm 0.13$ & $2.36^{\mathrm{A}} \pm 0.19$ \\
\hline Fiber (\%) & $0.81^{\mathrm{C}} \pm 0.06$ & $1.14^{\mathrm{B}} \pm 0.10$ & $1.34^{A \mathrm{R}} \pm 0.09$ & $1.58^{\mathrm{A}} \pm 0.17$ & $1.15^{\mathrm{R}} \pm 0.08$ & $1.24^{\mathrm{B}} \pm 0.07$ & $1.32^{\mathrm{AB}} \pm 0.05$ \\
\hline $\begin{array}{c}\text { Carbohydrate* } \\
(\%)\end{array}$ & $\begin{array}{l}48.49^{A} \\
\pm 0.16\end{array}$ & $47.94^{A} \pm 0.22$ & $47.31^{\mathrm{AB}} \pm 0.19$ & $47.10^{R} \pm 0.20$ & $47.81^{\mathrm{A}} \pm 0.14$ & $47.45^{\mathrm{AR}} \pm 0.28$ & $47.16^{R} \pm 0.42$ \\
\hline $\begin{array}{l}\text { Energy value } \\
\text { (kcal } 100 \mathrm{~g}^{-1} \text { ) }\end{array}$ & $332.29^{A} \pm 1.8$ & $330.23^{\mathrm{AB}} \pm 1.4$ & $328.36^{A B} \pm 2.1$ & $327.91^{\mathrm{B}} \pm 2.6$ & $329.73^{\mathrm{AR}} \pm 2.9$ & $328.59^{\mathrm{AR}} \pm 2.7$ & $327.82^{\mathrm{R}} \pm 2.5$ \\
\hline
\end{tabular}

(Means $\pm S E$ ).

A.B.C: Means with the same letter in the same raw are not significantly different $(p>0.05)$.

* Total carbohydrate was calculated by difference.

\section{Physical analyses of cake:}

Determination of weight, volume and specific volume for fresh cake prepared by substitution of WF with IBHP and IBLP at dose level of $5 \mathrm{kGy}$ :

Data in Table (4) shows that, increasing of IBHP and IBLP substitution level increased the weight property, but no significant different between all samples treatment and control sample. This might be attributed to the higher fiber content for IBHP and IBLP which increased the weight. These results are in agreement with (Sankhon et al., 2013; Khalifa et al., 2015). On the other hand, a significant increase in cake volume and Specific volume were noted with an increase in the IBHP and IBLP level. The control sample had the lowest value of weight, Volume and Specific volume compared to all samples. While the highest value of volume and specific volume were recorded in cake prepared from WF replacement with $1.5 \%$ IBHP and $1 \%$ IBLP, these values were $\left(120 \mathrm{~cm}^{3}\right.$ and $\left.2.14 \mathrm{~cm}^{3} / \mathrm{g}\right)$ and $\left(126 \mathrm{~cm}^{3}\right.$ and $\left.2.13 \mathrm{~cm}^{3} / \mathrm{g}\right)$ respectively. These results are in agreement with (Hafez, 2012;Al-Sayed and Ahmed, 2013;Sankhon et al., 2013). 
Table (4) : Weight, volume and specific volume of cake containing substituted flour with different levels of $I B H P$ and IBLP at dose level of $5 k G y$.

\begin{tabular}{|c|c|c|c|c|}
\hline \multicolumn{2}{|c|}{$\begin{array}{c}\text { Substitution } \\
(\%)\end{array}$} & Weight (g) & Volume $\left(\mathrm{cm}^{3}\right)$ & Specific volme $\left(\mathrm{cm}^{3} / \mathrm{g}\right)$ \\
\hline \multicolumn{2}{|c|}{ Control } & $54^{\mathrm{A}} \pm 1.61$ & $98^{\mathrm{F}} \pm 1.73$ & $1.81^{\mathrm{C}} \pm 0.023$ \\
\hline \multirow{3}{*}{ IBHP } & $1.5 \%$ & $56^{\mathrm{A}} \pm 1.61$ & $120^{\mathrm{P}} \pm 1.89$ & $2.14^{\mathrm{A}} \pm 0.029$ \\
\hline & $3 \%$ & $57.5^{\mathrm{A}} \pm 1.21$ & $114^{\mathrm{D}} \pm 2.02$ & $1.99^{\mathrm{B}} \pm 0.005$ \\
\hline & $4.5 \%$ & $56^{\mathrm{A}} \pm 1.47$ & $110^{\mathrm{BC}} \pm 1.52$ & $1.96^{\mathrm{B}} \pm 0.041$ \\
\hline \multirow{3}{*}{ IBLP } & $1 \%$ & $59^{\mathrm{A}} \pm 1.44$ & $126^{\mathrm{A}} \pm 1.44$ & $2.13^{\mathrm{A}} \pm 0.026$ \\
\hline & $2 \%$ & $57.5^{\mathrm{A}} \pm 1.21$ & $116^{\mathrm{BC}} \pm 1.15$ & $2.02^{\mathrm{B}} \pm 0.023$ \\
\hline & $3 \%$ & $56.5^{\mathrm{A}} \pm 1.84$ & $113^{\mathrm{CD}} \pm 1.60$ & $2^{\mathrm{B}} \pm 0.037$ \\
\hline
\end{tabular}

(Means $\pm S E)$.

A.B.C: Means with the same letter in the same column are not significantly different $(p>0.05)$.

Hunter-lab color values of different cake treatments as affected by substitution of WF with IBHP and IBLP at dose level of $5 \mathrm{kGy}$ :

All color data are expressed as Hunter L*, $a^{*}$ and $b^{*}$ values corresponding to lightness, redness, and yellowness, respectively. The results of Hunterlab color for cake produced by using $100 \%$ WF as a control sample and cake samples which substituted with $1.5,3,4.5 \%$ IBHP as well as $1,2,3 \%$ IBLP immediately after processing are presented in Table (5).

From these data, it could be observed that, increasing of IBHP and IBLP substitution level decreased the Lightness $\left(\mathrm{L}^{*}\right)$, redness $\left(\mathrm{a}^{*}\right)$, yellowness $\left(\mathrm{b}^{*}\right)$, Chroma and total intensity values of the crust for all cake treatments compared to control sample. Also, these data showed that, increasing of IBHP and IBLP substitution level decreased the Lightness $\left(L^{*}\right)$, redness $\left(a^{*}\right)$ and total intensity values of the crumb. But, it was increased the yellowness $\left(b^{*}\right)$ and Chroma values of the crumb for all cake treatments compared to control sample. These results are in agreement with (Sankhon et al., 2013).

The crumb of the control cake was lighter and more yellow compared to the tested cakes. It was well known that during cake baking, the crumb, does not reach temperatures above $100^{\circ} \mathrm{C}$, so the Millard or caramelization reactions fail to take place. Therefore, the resulted of crumb color of tested cake was due to the color of the used substituted materials and their interactions(Gomez et al., 2008).

In general, the changes in crust and crumb color of different cake treatments as affected by substitution of WF with IBHP and leaf powders might be attributed to the green color in the broccoli caused by the presence of chlorophyll pigment.

Total phenolic compounds and antioxidant activity of different WF cakes substituted with IBHP and IBLP at dose level of $5 \mathrm{kGy}$ :

The total phenolic compounds content (TPC) and the DPPH radical scavenging activities of all formulated cakes were investigated; data is presented in Table (6).

From these data it could be found that non-significant differences $(p>0.05)$ were noticed in TPC content between all cake sample treatments and control sample. Excepting, the cake sample containing $2 \%$ IBLP where it had the highest TPC content being 1.66 ( $\mathrm{mg} \mathrm{GAE} \mathrm{g}^{-1}$ ). Also, these results showed that, increasing of IBHP and IBLP substitution level increased the TPC content. 
On the other hand a significant increase in the DPPH radical scavenging activities of all cake samples was noted with an increase in the IBHP and IBLP level. The highest DPPH radical scavenging activities were recorded in the cake sample containing 3\% IBHP being $7.82 \%$, followed by the cake sample containing $2 \%$ IBLP being $7.57 \%$. While the control sample had the lowest TPC content and
DPPH radical scavenging activity being 1.19 (mg GAE $\mathbf{g}^{-1}$ ) and $2.95 \%$, respectively.

In general, the results in Table (6) showed that, increasing of IBHP and IBLP substitution level increased the TPC content and the DPPH radical scavenging activities compared to control sample. This may be due to that increasing of phytochemicals as a result of increasing of IBHP and IBLP levels.

Table (5) : Hunter-lab color values of cake with different levels IBHP and IBLP powder at dose level of 5 $k G y$.

\begin{tabular}{|c|c|c|c|c|c|c|c|c|c|c|c|}
\hline \multirow{2}{*}{\multicolumn{2}{|c|}{$\begin{array}{c}\text { Substitution } \\
\%\end{array}$}} & \multicolumn{5}{|c|}{ Crust } & \multicolumn{5}{|c|}{ Crumb } \\
\hline & & $\mathbf{L}^{*}$ & $a^{*}$ & $\mathbf{b}^{*}$ & Chroma & $\begin{array}{c}\text { Total } \\
\text { intensity }\end{array}$ & $\mathbf{L}^{*}$ & $\mathbf{a}^{*}$ & $\mathbf{b}^{*}$ & Chroma & $\begin{array}{c}\text { Total } \\
\text { intensity }\end{array}$ \\
\hline \multicolumn{2}{|c|}{ Control } & 48.21 & 17.46 & 30.39 & 35.05 & 59.6 & 74.82 & 8.30 & 28.63 & 29.81 & 80.54 \\
\hline \multirow{3}{*}{$\hat{\underline{\theta}}$} & $1.5 \%$ & 47.98 & 12.93 & 28.55 & 31.34 & 57.31 & 63.16 & 4.81 & 28.90 & 29.29 & 69.62 \\
\hline & $3 \%$ & 45.44 & 11.47 & 26.67 & 29.03 & 53.92 & 59.30 & 4.39 & 29.58 & 29.9 & 66.41 \\
\hline & $4.5 \%$ & 43.05 & 9.96 & 24.50 & 26.44 & 50.52 & 56.53 & 2.80 & 30.33 & 30.46 & 64.21 \\
\hline \multirow{3}{*}{$\frac{\theta}{9}$} & $1 \%$ & 47.09 & 8.87 & 26.73 & 28.16 & 54.87 & 59.53 & 2.87 & 30.86 & 30.99 & 67.11 \\
\hline & $2 \%$ & 43.62 & 5.87 & 23.92 & 24.63 & 50.09 & 57.20 & 0.64 & 32.32 & 32.33 & 65.70 \\
\hline & $3 \%$ & 41.49 & 4.13 & 24.05 & 24.4 & 48.13 & 53.35 & -2.16 & 32.29 & 32.21 & 62.32 \\
\hline
\end{tabular}

$\left(L^{*}\right)$ : Lightness, $\left(a^{*}\right)$ : redness, $\left(b^{*}\right)$ : yellowness.

Table (6) : Total phenolic compounds and antioxidant activity of different WF cakes substituted with IBHP and IBLP at dose level of $5 k G y$.

\begin{tabular}{|c|c|c|c|}
\hline \multicolumn{2}{|c|}{$\begin{array}{c}\text { Substitution } \\
(\%)\end{array}$} & $\begin{array}{c}\text { TPC } \\
\left(\mathrm{mg} \mathrm{GAE} \mathrm{g}^{-1}\right)\end{array}$ & DPPH (\%) \\
\hline \multicolumn{2}{|c|}{ Control } & $1.19^{\mathrm{B}} \pm 0.043$ & $2.95 \%{ }^{\mathrm{C}} \pm 0.153$ \\
\hline \multirow{3}{*}{ IBHP } & $\mathbf{1 . 5 \%}$ & $1.27^{\mathrm{B}} \pm 0.055$ & $5.63 \% \%^{\mathrm{B}} \pm 0.393$ \\
\cline { 2 - 4 } & $\mathbf{3 \%}$ & $1.32^{\mathrm{B}} \pm 0.046$ & $7.82 \% \%^{\mathrm{A}} \pm 0.565$ \\
\cline { 2 - 4 } & $\mathbf{4 . 5 \%}$ & $1.22^{\mathrm{B}} \pm 0.055$ & $3.06 \%{ }^{\mathrm{C}} \pm 0.185$ \\
\hline \multirow{3}{*}{ IBLP } & $\mathbf{1 \%}$ & $1.31^{\mathrm{B}} \pm 0.057$ & $6.28 \%{ }^{\mathrm{B}} \pm 0.430$ \\
\cline { 2 - 4 } & $\mathbf{2 \%}$ & $1.66^{\mathrm{A}} \pm 0.033$ & $7.57^{\mathrm{A}}{ }^{\mathrm{A}} \pm 0.392$ \\
\cline { 2 - 4 } & $\mathbf{3 \%}$ & $1.20^{\mathrm{B}} \pm 0.066$ & $3.23 \%{ }^{\mathrm{C}} \pm 0.236$ \\
\hline
\end{tabular}

(Means $\pm S E)$

A.B.C: Means with the same letter in the same column are not significantly different ( $p>0.05)$. 
The Antioxidant activity could enhance the bakery products shelf-life stability and retain the oil oxidation especially in cake products using the sources that may provide phytochemicals as natural components, like fruit, vegetable and their residues. These results are in accordance with those obtained by (Lu et al., 2010; Ahmed, 2014; Badr, 2015; Khalifa et al., 2015).

Microbiological quality attributes of cake containing IBHP and IBLP at dose level of $5 \mathrm{kGy}$ at difference levels during storage at room temperature for 18 day:

It could be observed from the data in Table (7) that control sample had higher total bacterial and mold \& yeasts counts as compared to other cake samples which prepared with IBHP and IBLP at any time of storage at room temperature for 18 days. The total bacterial and mold \& yeasts counts of cake samples fortified with IBHP and IBLP were decreased with increasing the percentage of replacement $(1.5,3$ and $4.5 \%)$ for IBHP and (1,2 and 3$)$ for IBLP These results are in agreement with those obtained by (Ibrahim et al., 2013) who found the microbial number in cake decreased as the percent of Clove essential oil. It is clear from the table that the total bacterial count and mold \& yeasts were very low at zero time of storage ( $<100 \mathrm{cfu} / \mathrm{g})$. Also, from the same table, it could be noticed that, total bacterial and mold \& yeasts counts of all cake treatments were also affected by storage period.

Table (7): Hunter-lab color values of cake with different levels IBHP and IBLP powder at dose level of 5 $k G y$.

\begin{tabular}{|c|c|c|c|c|c|c|c|c|}
\hline \multirow{7}{*}{ 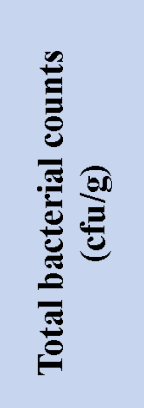 } & \multirow{3}{*}{$\begin{array}{c}\text { Storage } \\
\text { period } \\
\text { (days) }\end{array}$} & \multirow{3}{*}{ Control } & \multicolumn{6}{|c|}{ Treatments } \\
\hline & & & \multicolumn{3}{|c|}{ IBHP } & \multicolumn{3}{|c|}{ IBLP } \\
\hline & & & $1.5 \%$ & $3 \%$ & $4.5 \%$ & $1 \%$ & $2 \%$ & $3 \%$ \\
\hline & $\mathbf{0}$ & $8 \times 10^{1}$ & $6 \times 10^{1}$ & $5 \times 10^{1}$ & $5 \times 10^{1}$ & $7 \times 10^{1}$ & $8 \times 10^{1}$ & $6 \times 10^{1}$ \\
\hline & 6 & $22 \times 10^{2}$ & $18 \times 10^{2}$ & $19 \times 10^{2}$ & $16 \times 10^{2}$ & $19 \times 10^{2}$ & $18 \times 10^{2}$ & $18 \times 10^{2}$ \\
\hline & 12 & $63 \times 10^{2}$ & $54 \times 10^{2}$ & $49 \times 10^{2}$ & $48 \times 10^{2}$ & $52 \times 10^{2}$ & $44 \times 102$ & $41 \times 10^{2}$ \\
\hline & 18 & $49 \times 10^{3}$ & $35 \times 10^{3}$ & $32 \times 10^{3}$ & $29 \times 10^{3}$ & $37 \times 10^{3}$ & $29 \times 10^{3}$ & $18 \times 10^{3}$ \\
\hline \multirow{4}{*}{ 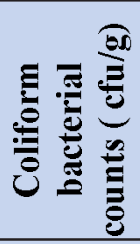 } & 0 & N.D & N.D & N.D & N.D & N.D & N.D & N.D \\
\hline & 6 & N.D & N.D & N.D & N.D & N.D & N.D & N.D \\
\hline & 12 & N.D & N.D & N.D & N.D & N.D & N.D & N.D \\
\hline & 18 & N.D & N.D & N.D & N.D & N.D & N.D & N.D \\
\hline \multirow{4}{*}{ 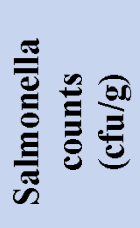 } & $\mathbf{0}$ & N.D & N.D & N.D & N.D & N.D & N.D & N.D \\
\hline & 6 & N.D & N.D & N.D & N.D & N.D & N.D & N.D \\
\hline & 12 & N.D & N.D & N.D & N.D & N.D & N.D & N.D \\
\hline & 18 & N.D & N.D & N.D & N.D & N.D & N.D & N.D \\
\hline \multirow{4}{*}{ 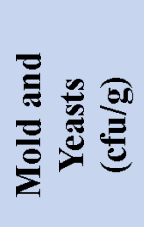 } & $\mathbf{0}$ & $6 \times 10^{1}$ & $5 \times 10^{1}$ & $5 \times 10^{1}$ & $4 \times 10^{1}$ & $6 \times 10^{1}$ & $4 \times 10^{1}$ & $4 \times 10^{1}$ \\
\hline & 6 & $12 \times 10^{2}$ & $11 \times 10^{2}$ & $9 \times 10^{2}$ & $9 \times 10^{2}$ & $10 \times 10^{2}$ & $10 \times 10^{2}$ & $8 \times 10^{2}$ \\
\hline & 12 & $59 \times 10^{2}$ & $54 \times 10^{2}$ & $51 \times 10^{2}$ & $47 \times 10^{2}$ & $56 \times 10^{2}$ & $52 \times 10^{2}$ & $48 \times 10^{2}$ \\
\hline & 18 & $64 \times 10^{3}$ & $58 \times 10^{3}$ & $59 \times 10^{3}$ & $56 \times 10^{3}$ & $59 \times 10^{3}$ & $55 \times 10^{3}$ & $52 \times 10^{3}$ \\
\hline
\end{tabular}


The total bacterial and mold \& yeasts counts were increased in control sample and other treatments with increasing storage time up to 18 days of storage, but at different counts depending on the type of added plant portion and their percentages.

On the other hand, the increase in total bacterial counts after zero time until the end of storage period for control and all cake treatments may be due to increasing simple nitrogen compound(such as amino acid) and fatty acids produced by hydrolysis of protein and fat during storage consequently lead to suitable conditions for growth of microorganisms. While, the increase rates of total bacterial and mold $\&$ yeasts counts for the samples containing IBHP and IBLP were lower than that control of sample during storage at room temperature for 18 day. This might be attributed to the effect of the antimicrobial compounds in broccoli. This opinion is in agreement with (Abdalla et al., 2007; Somaie et al., 2013). On the other hand, Coliform group and Salmonella weren't detected in all cakes during the storage period. These results agree with those obtained by (Khalifa et al., 2015). They recorded that coliform group wasn't detected in cake product and it also agree with those obtained by (Sahari and Asgari, 2013), Who recorded the absence of salmonella spp. in Bakery Products.

Sensory properties of cake prepared by substitution of WF with IBHP and IBLP at dose level of 5 kGy:

The effect of partial replacement with different ratio of IBHP (1.5, 3 and $4.5 \%)$ and IBLP at levels (1, 2 and $3 \%$ ) on the organoleptic quality characteristics of produced cake during storage at room temperature for 18 days is presented in Table(8). From the sensory evaluation results, it could be seen that, there were non-significant differences in appearance, taste and overall acceptability between the control cake and cake prepared by adding $1.5 \%$ and $1 \%$ IBHP and IBLP, respectively, but significant differences in appearance could be observed between cake prepared by adding $(3,4.5 \%)$ and $(2,3 \%)$ IBHP and IBLP, respectively compared to control cake sample. Also, from the same results, it could be observed that, there were no significant differences in crust color between control cake sample and cake prepared by adding 1.5\% IBHP, but significant differences in appearance could be observed between other different cake samples (except cake prepared by adding 1\% IBLP after 12 and 18 days) compared to control cake sample.

For crumb color, there were significant differences between control cake sample and all different cake samples, excepted cake prepared by adding $1.5 \%$ IBHP after 18 days.

Concerning the odor, it could be observed that, there were no significant difference between the control sample and cake prepared by all replacement levels.

From the same data in Table (8), it could be noticed that the control cake sample recorded the highest scores in all organoleptic characteristics except odor, while cake prepared by adding 3\% IBLP recorded the lowest scores in all organoleptic characteristics except odor, followed by cake prepared by adding $4.5 \%$ IBHP.

Change in color, odor and taste in cake may be due to aroma volatiles in raw materials used and also due to carmalization and millered reaction, as the protein contributed must have reached with the reduced sugar during the making process (Dhingra and Jood, 2004).

From these results, it could be observed that, there was a gradual decrease in all sensory characteristics for all different cake samples during storage periods.

The sensory characteristics liking results pointed out that a partial replacement of cake flour with less than or equal to (4.5 and $3 \%$ ) IBHP and IBLP, respectively in cake is satisfactory. This opinion is in agreement with (Lu et al., 2010). 
Table (8) : Sensory properties of cake different treatments as affected by IBHP and IBLP at dose level of 5 $k G y$ during storage at room temperature for 18 day.

\begin{tabular}{|c|c|c|c|c|c|c|c|}
\hline \multirow{2}{*}{ Treatment } & \multirow{2}{*}{ Control } & \multicolumn{3}{|c|}{ IBHP } & \multicolumn{3}{|c|}{ IBLP } \\
\hline & & $1.5 \%$ & $3 \%$ & $4.5 \%$ & $1 \%$ & $2 \%$ & $3 \%$ \\
\hline $\begin{array}{c}\text { Storage } \\
\text { (days) }\end{array}$ & \multicolumn{7}{|c|}{ Appearance } \\
\hline 0 & $9.5^{\mathrm{A} a} \pm 0.16$ & $9.2^{\mathrm{A} a} \pm 0.23$ & $8.4^{\mathrm{Abc}} \pm 0.19$ & $7.8^{\mathrm{Acd}} \pm 0.25$ & $8.9^{\mathrm{Aab}} \pm 0.20$ & $7.9^{\mathrm{Acd}} \pm 0.27$ & $7.2^{\mathrm{Ad}} \pm 0.28$ \\
\hline 6 & $8.9^{A B a} \pm 0.25$ & $8.8^{\mathrm{AB}} \pm 0.33$ & $7.9^{\mathrm{Abc}} \pm 0.18$ & $7.5^{\mathrm{ABc} d} \pm 0.37$ & $8.5^{\mathrm{Aab}} \pm 0.27$ & $7.5^{\mathrm{ABcd}} \pm 0.30$ & $6.8^{\mathrm{Ad}} \pm 0.24$ \\
\hline 12 & $8.1^{\mathrm{Ba}} \pm 0.25$ & $7.9^{\mathrm{Ba}} \pm 0.39$ & $7.1^{\mathrm{Bbc}} \pm 0.15$ & $6.8^{\mathrm{B}} \pm 0.17$ & $7.7^{\mathrm{Bah}} \pm 0.15$ & $6.9^{\mathrm{BC}} \pm 0.28$ & $5.9^{\mathrm{Bd}} \pm 0.30$ \\
\hline 18 & $7.1^{\mathrm{Ca}} \pm 0.37$ & $6.8^{\mathrm{Cab}} \pm 0.34$ & $6.3^{\mathrm{Cab}} \pm 0.20$ & $5.9^{\mathrm{Cbc}} \pm 0.23$ & $6.5^{\mathrm{cab}} \pm 0.29$ & $6.1^{\mathrm{Cb}} \pm 0.28$ & $5.2^{\mathrm{Bc}} \pm 0.28$ \\
\hline \multicolumn{8}{|c|}{ Crust color } \\
\hline $\mathbf{0}$ & $9.1^{\mathrm{Aa}} \pm 0.21$ & $8.4^{\mathrm{Aab}} \pm 0.31$ & $7.7^{\mathrm{Abc}} \pm 0.26$ & $7.1^{\mathrm{Acd}} \pm 0.25$ & $8.1^{\mathrm{Ab}} \pm 0.28$ & $7.6^{\mathrm{Abc}} \pm 0.24$ & $6.8^{\mathrm{Ad}} \pm 0.23$ \\
\hline 6 & $8.6^{\mathrm{ABa}} \pm 0.22$ & $7.9^{\mathrm{Aab}} \pm 0.34$ & $7.3^{\mathrm{ABb}} \pm 0.22$ & $6.5^{\mathrm{ABcd}} \pm 0.26$ & $7.7^{\mathrm{ABh}} \pm 0.27$ & $7.1^{\mathrm{ABb}} \pm 0.27$ & $6.1^{\mathrm{ABd}} \pm 0.24$ \\
\hline 12 & $8^{\mathrm{Ba}} \pm 0.29$ & $7.4^{\mathrm{ABah}} \pm 0.38$ & $6.8^{\text {BChcd }} \pm 0.25$ & $6.1^{\mathrm{BCde}} \pm 0.22$ & $7.1^{\mathrm{Babc}} \pm 0.25$ & $6.4^{\mathrm{BCcde}} \pm 0.32$ & $5.7^{\mathrm{BCe}} \pm 0.30$ \\
\hline 18 & $6.9^{\mathrm{Ca}} \pm 0.27$ & $6.5^{\mathrm{Bab}} \pm 0.35$ & $6.1^{\mathrm{Cab}} \pm 0.19$ & $5.6^{\mathrm{cbc}} \pm 0.21$ & $6.1^{\mathrm{Cab}} \pm 0.19$ & $5.8^{\mathrm{cbc}} \pm 0.52$ & $5^{\mathrm{Cc}} \pm 0.27$ \\
\hline \multicolumn{8}{|c|}{ Crumb color } \\
\hline $\mathbf{0}$ & $8.8^{\mathrm{Aa}} \pm 0.22$ & $7.9^{\mathrm{Ab}} \pm 0.33$ & $6.6^{\mathrm{Acd}} \pm 0.17$ & $6^{\mathrm{Ad}} \pm 0.28$ & $7.1^{\mathrm{Ac}} \pm 0.31$ & $6.2^{\mathrm{Ad}} \pm 0.25$ & $5.1^{\mathrm{Ae}} \pm 0.22$ \\
\hline 6 & $8.4^{A B a} \pm 0.22$ & $7.5^{\mathrm{Ab}} \pm 0.41$ & $6.2^{\mathrm{Acd}} \pm 0.26$ & $5.7^{\mathrm{ABd}} \pm 0.23$ & $6.6^{\mathrm{ABC}} \pm 0.23$ & $5.9^{\mathrm{Acd}} \pm 0.24$ & $4.8^{\mathrm{ABe}} \pm 0.27$ \\
\hline 12 & $7.7^{\mathrm{Ba}} \pm 0.24$ & $6.9^{\mathrm{ABb}} \pm 0.34$ & $5.5^{\mathrm{B}} \pm 0.16$ & $5.1^{\mathrm{BC}} \pm 0.28$ & $5.9^{\mathrm{BC}} \pm 0.22$ & $5.1^{\mathrm{BC}} \pm 0.27$ & $4.1^{\mathrm{BCd}} \pm 0.25$ \\
\hline 18 & $6.8^{\mathrm{Ca}} \pm 0.30$ & $6.1^{\mathrm{B}} \pm 0.39$ & $5^{\mathrm{Bb}} \pm 0.17$ & $4.6^{\mathrm{Cbc}} \pm 0.22$ & $5.3^{\mathrm{Cb}} \pm 0.23$ & $4.5^{\mathrm{Bb}} \pm 0.22$ & $3.8^{\mathrm{Cc}} \pm 0.27$ \\
\hline \multicolumn{8}{|c|}{ Taste } \\
\hline $\mathbf{0}$ & $8.4^{\mathrm{Aa}} \pm 0.21$ & $7.8^{\mathrm{Aa}} \pm 0.34$ & $6.9^{\mathrm{Ab}} \pm 0.18$ & $5.7^{\mathrm{Ac}} \pm 0.28$ & $7.9^{\mathrm{Aa}} \pm 0.23$ & $6.5^{\mathrm{Ab}} \pm 0.26$ & $5.5^{\mathrm{Ac}} \pm 0.32$ \\
\hline 6 & $7.8^{\mathrm{Aa}} \pm 0.25$ & $7.2^{\mathrm{ABa}} \pm 0.38$ & $6.1^{\mathrm{Bb}} \pm 0.20$ & $5.2^{\mathrm{ABb}} \pm 0.32$ & $7.4^{\mathrm{ABa}} \pm 0.35$ & $5.8^{\mathrm{ABb}} \pm 0.29$ & $4.6^{\mathrm{Bc}} \pm 0.22$ \\
\hline 12 & $6.9^{\mathrm{Ba}} \pm 0.28$ & $6.4^{\mathrm{BCa}} \pm 0.44$ & $5.4^{\mathrm{Cb}} \pm 0.20$ & $4.5^{\mathrm{BCcd}} \pm 0.20$ & $6.7^{\mathrm{Ba}} \pm 0.22$ & $5.1^{\mathrm{BCh}} \pm 0.28$ & $3.8^{\mathrm{BCd}} \pm 0.29$ \\
\hline 18 & $5.5^{\mathrm{Ca}} \pm 0.28$ & $5.3^{\mathrm{Cab}} \pm 0.34$ & $4.5^{\mathrm{Dc}} \pm 0.18$ & $3.7^{\mathrm{ccd}} \pm 0.27$ & $5.8^{\mathrm{Ca}} \pm 0.25$ & $4.3^{\mathrm{Cc}} \pm 0.29$ & $3.1^{\mathrm{Cd}} \pm 0.27$ \\
\hline \multicolumn{8}{|c|}{ Odor } \\
\hline $\mathbf{0}$ & $8.3^{\mathrm{Aa}} \pm 0.31$ & $8^{\mathrm{Aa}} \pm 0.36$ & $7.8^{\mathrm{Aa}} \pm 0.22$ & $7.5^{\mathrm{Aa}} \pm 0.24$ & $8.2^{\mathrm{Aa}} \pm 0.25$ & $8.1^{\mathrm{Aa}} \pm 0.22$ & $7.9^{\mathrm{Aa}} \pm 0.33$ \\
\hline 6 & $7.8^{\mathrm{AB}} \pm 0.25$ & $7.7^{\mathrm{AB}} \pm 0.23$ & $7.6^{\mathrm{AB}} \pm 0.19$ & $7.2^{\mathrm{Aa}} \pm 0.27$ & $7.8^{\mathrm{ABa}} \pm 0.29$ & $7.6^{\mathrm{AB}} \pm 0.22$ & $7.5^{\mathrm{Aa}} \pm 0.31$ \\
\hline 12 & $6.7^{\mathrm{BCa}} \pm 0.37$ & $7^{\mathrm{BC}} \pm 0.12$ & $7.1^{\mathrm{Ba}} \pm 0.22$ & $6.8^{\mathrm{ABa}} \pm 0.22$ & $7.3^{\mathrm{BCa}} \pm 0.28$ & $7.2^{\mathrm{ABa}} \pm 0.23$ & $7.2^{\mathrm{ABa}} \pm 0.28$ \\
\hline 18 & $6.1^{\mathrm{Ca}} \pm 0.33$ & $6.5^{\mathrm{Ca}} \pm 0.16$ & $6.4^{\mathrm{Ca}} \pm 0.19$ & $6.4^{\mathrm{Ba}} \pm 0.17$ & $6.8^{\mathrm{Ca}} \pm 0.22$ & $6.6^{\mathrm{B} a} \pm 0.57$ & $6.5^{\mathrm{Ba}} \pm 0.24$ \\
\hline \multicolumn{8}{|c|}{ Overall acceptability } \\
\hline $\mathbf{0}$ & $8.9^{\mathrm{Aa}} \pm 0.18$ & $8.5^{\mathrm{Aab}} \pm 0.22$ & $7.8^{\mathrm{Abc}} \pm 0.24$ & $6.5^{\mathrm{Ad}} \pm 0.30$ & $8.2^{\mathrm{Aab}} \pm 0.31$ & $7.3^{\mathrm{Ac}} \pm 0.24$ & $5.9^{\mathrm{Ad}} \pm 0.27$ \\
\hline 6 & $8.3^{\mathrm{AB}} \pm 0.29$ & $8^{\mathrm{ABa}} \pm 0.22$ & $7^{\mathrm{Bb}} \pm 0.22$ & $6.1^{\mathrm{ABc}} \pm 0.31$ & $7.8^{\mathrm{Aa}} \pm 0.27$ & $6.8^{\mathrm{ABb}} \pm 0.29$ & $5.5^{A B d} \pm 0.29$ \\
\hline 12 & $7.9^{\mathrm{Ba}} \pm 0.28$ & $7.7^{\mathrm{Ba}} \pm 0.22$ & $6.4^{\mathrm{Bb}} \pm 0.15$ & $5.4^{\mathrm{BCC}} \pm 0.25$ & $7.4^{\mathrm{Aa}} \pm 0.19$ & $6.1^{\mathrm{BCl}} \pm 0.25$ & $4.8^{\mathrm{BCC}} \pm 0.25$ \\
\hline 18 & $6.9^{\mathrm{Ca}} \pm 0.38$ & $6.7^{\mathrm{Ca}} \pm 0.22$ & $5.5^{\mathrm{Cb}} \pm 0.16$ & $4.9^{\mathrm{cbc}} \pm 0.34$ & $6.5^{\mathrm{Ba}} \pm 0.27$ & $5.3^{\mathrm{cbc}} \pm 0.31$ & $4.4^{\mathrm{Cc}} \pm 0.35$ \\
\hline
\end{tabular}

(Means $\pm S E$ )

A.B.C: Means with the same letter in the same column are not significantly different ( $p>0.05)$. a.b.c: Means with the same letter in the same row are not significantly different $(p>0.05)$. 


\section{CONCLUSIONS}

The present study indicated the possibility of formulating cake using different levels of IBHP and IBLP at dose level of $5 \mathrm{KGy}$ as partial replacement of WF $(72 \%)$ to produce a low caloric cake with improvement the nutritional value, bioactive components, antioxidant and antimicrobial benefits to cakes during room temperature storage. In addition to, the properties of IBHP and IBLP were changed the sensory cakes characteristics, as the odor became more specific, the sensation for sweetness was weaker, the color of the crust and the crumb was green-brown. The shape and the crumb tenderness were discernible, but close to those of the control cake. Also the cakes containing IBHP and IBLP showed satisfactory physical properties.

\section{REFERENCES}

- Abdalla, A.E.; Darwish, S.M.; Ayad, E.H. and ElHamahmy, R.M. (2007): Egyptian mango by-product 2: Antioxidant and antimicrobial activities of extract and oil from mango seed kernel. Food Chem., 103(4): 1141.

- Ahmed, A.R. (2014): Influence of chemical properties of wheat-lupine flour blends on cake quality. Am. J. Food Technol., 2: 67.

- Al-Sayed, H.M.A. and Ahmed, A.R. (2013): Utilization of watermelon rinds and sharlyn melon peels as a natural source of dietary fiber and antioxidants in cake. Ann.Agric. Sci., 58(1): 83.

- Ali, M.A. and Halim, M.A. (2013): Bread made from wheat flour and white sesame flour in presences of natural improver. Pak. J. Nut., 12(4): 353.

- Alothman, M.; Bhat, R and Karim, A.A. (2009): Effects of radiation processing on phytochemicals and antioxidants in plant produce.Trends in Food Sci. Technol., 20(2): 201.

- A.A.C.C. (1983): American Association of Cereal Chemists, Cereal Laboratory Methods, Method 46-09. (Am. Assoc. Cereal Chem., St. Paul, MN), $7^{\text {th }}$ Ed. Marcel Dekker, Inc., New York.
- A.A.C.C. (1996): American Association of Cereal Chemists. Approved Methods of A.A.C.C. Published by the American Association of Cereal Chemists. Inc., St. Paul, Minnesota, USA, pp. 4, 13 and 61.

- A.O.A.C. (2012): Official Methods of Analysis of the Association of Official Analytical Chemestis, $19^{\text {th }}$ ed, Maryland, USA.

- APHA. (1992): American Public Health Association. Compendium of methods for the microbiological examination of foods. A.P.I.A. Inc. Washington, D.C., USA.

- Arabshahi-Delouee, S. and Urooj, A. (2007): Antioxidant properties of various solvent extracts of mulberry (Mocus indica L.) leaves. Food Chem., 102: 1233.

- Badr, S.A. (2015): Quality and antioxidant properties of pan bread enriched with watermelon rind powder. Curr. Sci. Int., 4(01): 117.

- Blasa, M.; Gennari, L.; Argelino, D. and Ninfali, P. (2010): Fruit and vegetable antioxidants in health. In: Bioactive Foods in Promoting Health. Fruits and Vegetables. Eds R.R. Watson, V.B. Preedy Elsevier Academic Press Inc, San Diego, USA.

- Caillet, S.; Cote, J.; Sylvain, J.F. and Lacroix, M. (2012): Antimicrobial effects of fractions from cranberry products on the growth of seven pathogenic bacteria. Food Control, 23: 419.

- Dhingra, D.; Michael, M. and Rajput, H. (2012): Physico-chemical characteristics of dietary fibre from potato peel and its effect on organoleptic characteristics of biscuits. J. Agric. Eng., 49: 25.

- Dhingra, S. and Jood, S. (2004): Effect of flour blending on functional, baking and organoleptic characteristics of bread. Int. J. Food Sci. Technol., 39(2): 213.

- Dixon, G.R. (2007): Vegetable brassicas and related crucifers. Oxfordshire, UK, CAB International.

- FAO. (1979): Manuals of food-quality controls, 4, microbiological analysis. Food and Agriculture organization of the united nations. Rome, PP. C9-12 and DI-33.

- FAO. (2003): Food Energy-Methods of Analysis and Conversion Factors. Food and Nutrition Paper, Rome, 77. 
- Galanakis, C.M.; Tornberg, E. and Gekas, V. (2010): Dietary fiber suspensions from olive mill wastewater as potential fat replacements in meatballs. Food Sci. Technol., 43: 1018 .

- Ghadi, F.E.; Ghara, A.R. and Ghanbari, T. (2015): Effect of gamma irradiation on the total phenolic content and free radical -scavenging activity of iranian date palm mazafati (Phoenix Dactylifera L.). IJLRST, 4(5): 149.

- Giombelli, A.; Hammerschmitt, D.; Cerutti, M.F.; Chiarini, E.; Landgraf, M.; Franco, B.D. and Destro, M.T. (2015): High pressure spray with water shows similar efficiency to trimming in controlling microorganisms on poultry carcasses. Poult. Sci., 94: 2589.

- Gomez, M.; Oliete, B.; Rosell, C.M.; Pando, V. and Fernandez, E. (2008): Studies on cake quality made of wheat-chickpea flour blends. Food Sci. Technol., 41(9): 1701-1709.

- Gourley, G. (2003): Vegetables: a user's guide. Wellington, New Zealand, NZ Vegetable \& Potato Growers' Federation Inc.

- Gulcin, I.; Kufrevioglu, O.I.; Oktay, M. and Buyukokuroglu, M.E. (2004): Antioxidant, antimicrobial, antiulcer and analgesic activities of nettle (Urtica dioica L.). J. Ethnopharmacol., 90: 205.

- Hafez, A.A. (2012): Physico-chemical and sensory properties of cakes supplemented with different concentration of marjoram. Au. J. Basic. Appl. Sci., 6(13): 463.

- Hanato, T.; Kagawa, H.; Yasuhara, T. and Okuda, T. (1988): Two new flavonoids and other constituents in licorice root: their relative astringency and radical scavenging effects. Chem. Pharm. Bull. 36: 2090.

- Higdon, J.V.; Delage, B.; Williams, D.E. and Dashwood, R.H. (2007): Cruciferous vegetables and human cancer risk: epidemiologic evidence and mechanistic basis. Pharmacol. Res., 55(3): 224.

- Ibrahim, M.I.; El-Ghany, M.A. and Ammar, M.S. (2013): Effect of clove essential oil as antioxidant and antimicrobial agent on cake shelf life. World J. Dairy Food Sci., 8(2): 140.

- Jahangir, M.; Kim, H.K.; Choi, Y.H. and Verpoorte,
R. (2009): Health-affecting compounds in Brassicaceae. Comprehensive Reviews in. Food Sci.Food Safety, 8(2): 31.

- Kaack, K. and Pedersen, L. (2005): Low Energy Chocolate Cake with Potato Pulp and Yellow Pea Iulls. European Food Research and Technology, 221: 367.

- Khaki, M.; Sahari, M.A. and Barzegar, M. (2012): Evaluation of antioxidant and antimicrobial effects of Chamomile (Matricaria chamomilla L.) essential oil on cake shelf life. J. Med. Plants, 3(43): 9.

- Khalifa, I.; Barakat, H.; El-Mansy, H.A. and Soliman, S.A. (2015): Physico-chemical, organolyptical and microbiological characteristics of substituted cupcake by potato processing residues. Food Nutr. Sci., 6(1): 83 .

- Kotsianis, I.S.; Giannou, V. and Tzia, C. (2002): Production and packaging of bakery products using MAP technology. Trends in Food Sci. and Technol., 13: 319.

- Lister, C.E. and Bradstock, M. (2003): Antioxidants : a health revolution : all you need to know about antioxidants. Christchurch, N.Z., New Zealand Institute for Crop \& Food Research.

- $\quad$ Lu, T.; Lee, C.Y.; Mau, J. and Lin ,S. (2010): Quality and antioxidant property of green tea sponge cake. Food Chem., 119: 1090 .

- Madhu, I. and Kochhar, A. (2014): Proximate composition, available carbohydrates, dietary fibre and antinutritional factors of Broccoli (Brassica oleracea L. Var. Italica Plenck) leaf and floret powder. Biosci. Discov., 5(1): 45 .

- Maffei, D.F.; Alvarenga, V.O.; Sant'Ana, A.S. and Franco, B.D. (2016): Assessing the effect of washing practices employed in Brazilian processing plants on the quality of ready-to-eat vegetables. LWT - Food Sci. Technol., 69: 474.

- Mahro, B. and Timm, M. (2007): Potential of biowaste from the food industry as a biomass resource. Eng. Life Sci., 7(5): 457 .

- Mai, T.T.; Chen, X.D. and Southern, C. (2007): Reducing oil content of fried potato crisps considerably using a'sweet' pre-treatment technique. J. Food Eng., 
80(2): 719 .

- Masoodi, F.A.; Sharma, B. and Chauhan, G.S. (2002): Use of apple pomace as a source of dietary fiber in cakes. Plant Foods Hum. Nutr., 57: 121.

- Menon, L.; Majumdar, S.D. and Ravi, U. (2014): Mango (Mangifera indica L.) kernel flour as a potential ingredient in the development of composite flour bread. Indian J. Nat. Prod. Resour., 5(1): 75.

- Moraes, E.A.; Dantas, M.; Morais, D.; Silva, C.; Castro, F.; Martino, H. and Ribeiro, S. (2010): Sensory evaluation and nutritional value of cakes prepared with whole flaxseed flour. Food Sci. Technol., 30: 974.

- Nanditha, B. and Prabhasankar, P. (2009): Antioxidants in bakery products: A review. Crit. Rev. Food Sci. Nutr., 49: 1.

- O'Shea, N.; Arendt, E.K. and Gallagher, E. (2012): Dietary fibre and phytochemical characteristics of fruit and vegetable by-products and their recent applications as novel ingre- dients in food products. Innovative Food Sci. Emerg. Technol., 16: 1.

- Patsioura, A.; Galanakis, C.M. and Gekas, V. (2011): Ultra-filtration optimization for the recovery of $\beta$-glucan from oat mill waste. J. Membr. Sci., 373: 53.

- Perera, A.; Lister, C.E.; Hedges, L. and Sanmugam, D. (2007): Hot potatoes \& cool bananas: healthy food what, why \& how. Singapore, SNP International Publishing.

- Podsedek, A. (2007): Natural antioxidants and antioxidant capacity of Brassica vegetables: areview. LWT. Food Sci.Technol., 40(1): 1.

- Prokopov, T.; Goranova, Z.; Baeva, M.; Slavov, A. and M.Galanakis, C. (2015): Effects of powder from white cabbage outer leaves on sponge cake quality. Int. Agrophys., 29: 1.

- Rodríguez, R.; Jimenez, A.; Fernández-Bolaños, J.; Guillén, R. and Heredia, A. (2006): Dietary fibre from vegetable products as source of functional ingredients. Trends in Food Sci. Technol., 17: 3.
- Sabouri, Z.; Barzegar, M.; Sahari, M.A. and Naghdi Badi, H. (2012): Antioxidant and antimicrobial potential of Echinacea purpurea extract and its effect on extension of cake shelf life. J. Med. Plants, 3(43): 28.

- Sahari, M.A and Asgari, S. (2013): Effects of Plants Bioactive Compounds on Foods Microbial Spoilage and Lipid Oxidation. Food Sci.Technol., 1(3): 52.

- Sankhon, A.; Amadou, I. and Yao, W.R. (2013): Application of resistant starch in bread: processing, proximate composition and sensory quality of functional bread products from wheat flour and African locust bean (Parkia biglobosa) flour. Agric. Sci., 4(05): 122.

- Santos, A.C.; Yassunaka, N.N.; Ruiz, S.P.; Schneider, V.V.A.; Visentainer, J.V. and Madrona, G.S. (2014): Sensory and Physicochemical Study of Carrot Leaf Sponge Cake. Rev. Bras. Pesquisa em Alimentos, 4: 41.

- Somaie, S.; Ashraf, k. and Zahra, H. (2013): Antimicrobial activity of methanol extract of (Opuntia stricta $F$. Inter. Res. J. Appl. Basic Sci., 7(12): 907.

- Sudha, M.L.; Baskaran, V. and Leelavathi, K. (2007): Apple pomace as a source of dietary fiber and polyphenols and its effect on the rheological characteristics and cake making .Food Chem., 104: 686.

- USDA. (2011): Nutritive value of broccoli leaves (cited from http://nutritiondata.self.com/facts/vegetables-andvegetables -products/broccoli/leaves).

- Variyar, P.S.; Bandyopadhyay, C. and Thomas, P. (1998): Effect of $\gamma$-irradiation on the phenolic acid of some Indian spices. Inter. J. Food Sci Technol., 33: 533.

- Yuan, G.; Sun, B.; Yuan, J. and Wang, Q. (2010): Effect of 1-methylcyclopropene on shelf life, visual quality, antioxidant enzymes and health-promoting compounds in broccoli florets. Food Chem., 118: 774.

- Zhang, D. and Hamauzu, Y. (2004): Phenolics, ascorbic acid, carotenoids and antixidant activity of broccoli and their changes during conventional and microwave cooking. Food Chem., 88: 503. 
مح

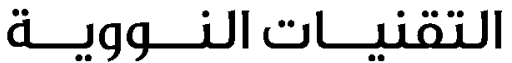 فى العلوم التطبيقية}

مجلد 6، عدد 1 ، ص 13 : 29 ، (2018)

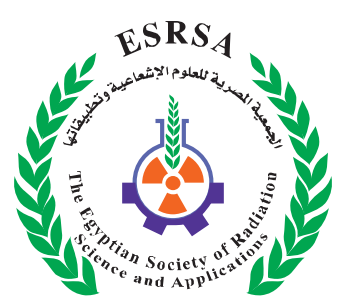

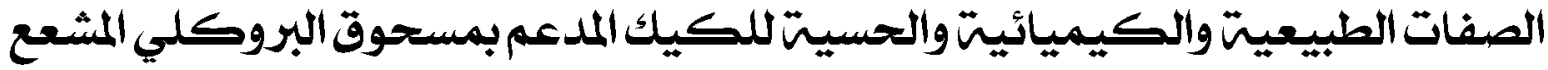

حسن حسن على خلف'، رؤوف محمد عبداللّه السعدنى'، مرفت محمد أنور"، حامد علي فرحات

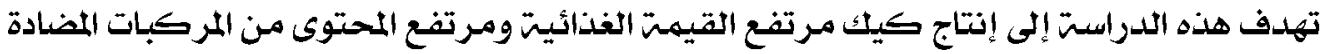

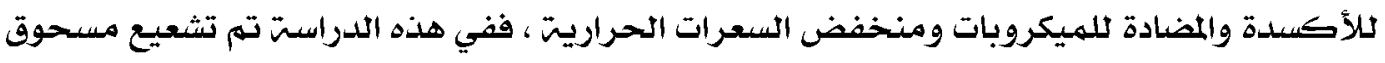

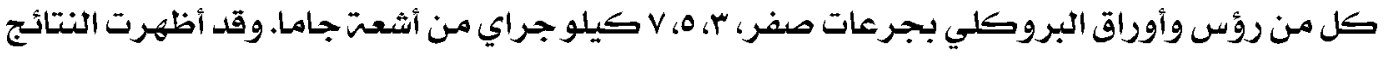

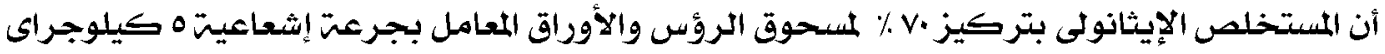

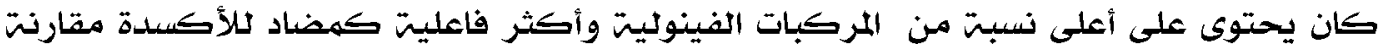

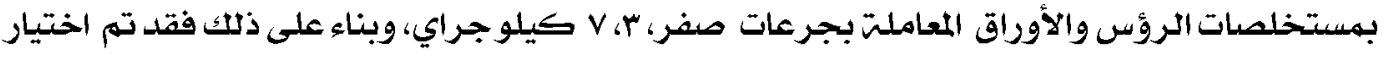

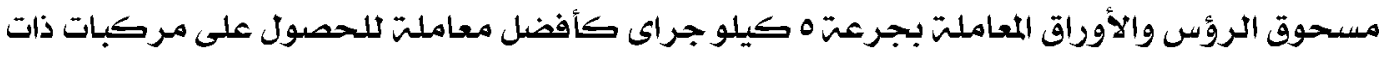

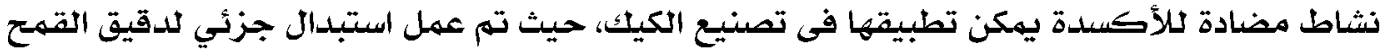

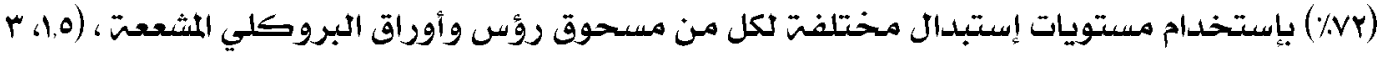

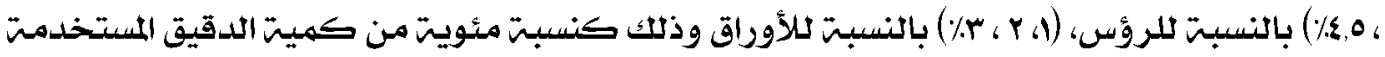

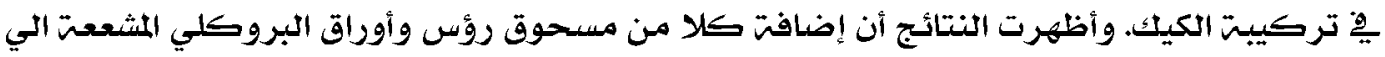

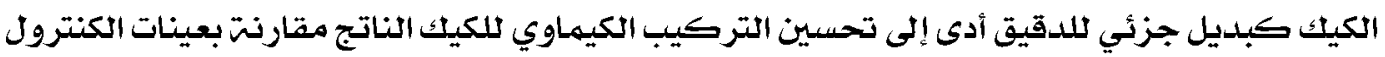

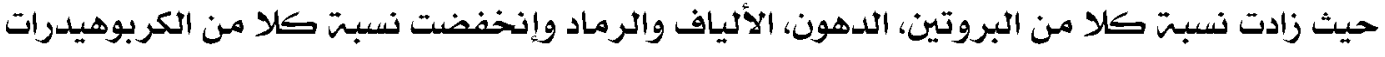

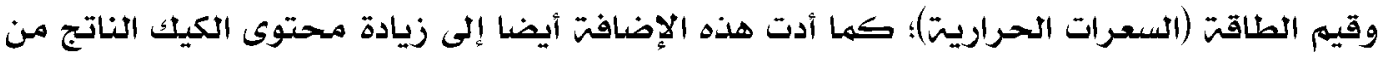

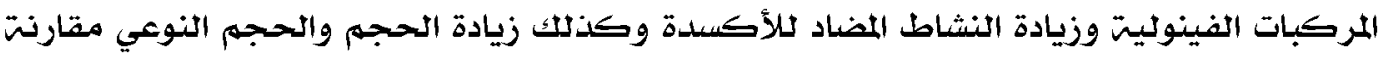

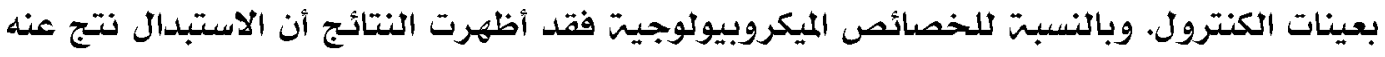

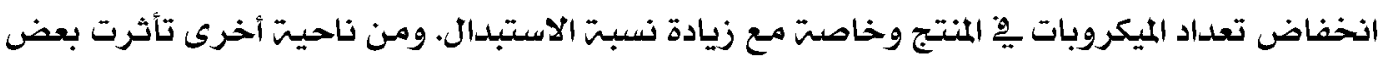

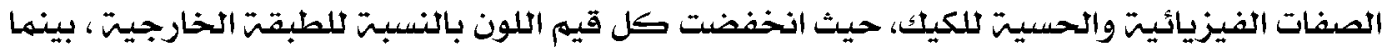

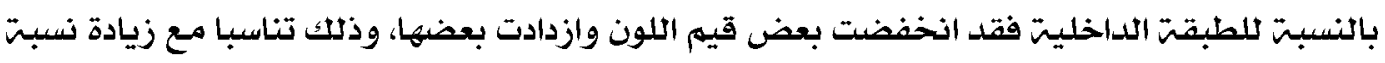

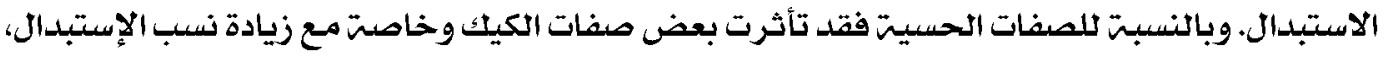

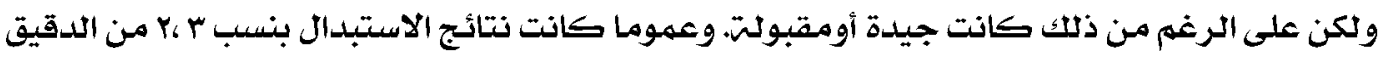

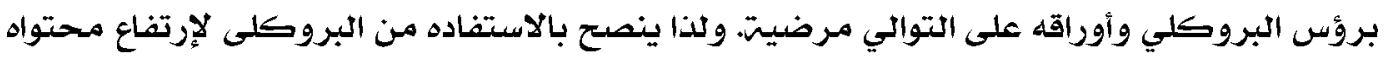

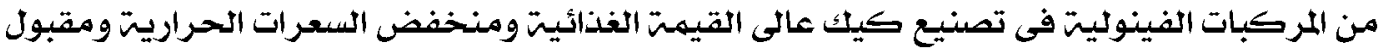

$$
\text { لدى المستهليك. }
$$


